\title{
A phase II study of epigenetic therapy with hydralazine and magnesium valproate to overcome chemotherapy resistance in refractory solid tumors
}

\author{
Myrna Candelaria ${ }^{2}$, Dolores Gallardo-Rincón ${ }^{3}$, Claudia Arce ${ }^{2}$, Lucely Cetina ${ }^{2}$, \\ Jose Luis Aguilar-Ponce ${ }^{3}$, Oscar Arrieta ${ }^{3}$, Alberto Serrano², Carlos Perez- \\ Plasencia1 ${ }^{1}$ Aurora Gonzalez-Fierro ${ }^{1}$, Erik de la Cruz-Hernandez ${ }^{1}$, \\ Alma Revilla-Vazquez ${ }^{4}$, Alma Chavez-Blanco', Catalina Trejo-Becerril ${ }^{1}$, \\ Enrique Perez-Cardenas' ${ }^{1}$ Lucia Taja-Chayeb ${ }^{1}$, Maria F Camargo ${ }^{1}$, \\ Elizabeth Robles ${ }^{2}$ and Alfonso Dueñas-Gonzalez*1
}

Address: ${ }^{1}$ Unidad de Inv. Biom. en Cáncer, IIB, UNAM/INCAN, México, ${ }^{2}$ Division of Clinical Research, INCAN, Mexico, ${ }^{3}$ Medical Division, INCAN, Mexico and ${ }^{4}$ Lab. de Desarrollo de Métodos Analiticos, FES-Cuautitlan, UNAM, Mexico

Email: Alfonso Dueñas-Gonzalez* - alfonso_duenasg@yahoo.com

* Corresponding author

from 24th Annual Meeting of the National Cancer Institute of Mexico Mexico City, Mexico. 14-17 February 2007

Published: 5 February 2007

BMC Cancer 2007, 7(SuppI I):A27 doi:10.1 186/I47I-2407-7-SI-A27

This article is available from: http://www.biomedcentral.com/I47I-2407/7/SI/A27

(c) 2007 Candelaria et al; licensee BioMed Central Ltd.

\section{Background}

Chemotherapy resistance, either innate or acquired requires for its development, expression changes on a large number of genes therefore, it has been hypothesized that epigenetic-mediated changes could be the driving force for chemotherapy resistance. Aberrant DNA methylation and histone deacetylation are the main epigenetic alterations in cancer, hence we hypothesized that hydralazine, a DNA methylation inhibitor and valproate, a histone deacetylase inhibitor may overcome resistance in refractory solid tumors.

\section{Methodology}

This is a MinExpSize 2-stage phase II open-label, singlearm study in which patients with advanced solid tumors who were progressing at the second or third cycle of first, second, third, fourth or fifth line of palliative chemotherapy were included. Patients were typed for acetylator phenotype and then treated with hydralazine at a daily dose of $182 \mathrm{mg}$ for rapid or $83 \mathrm{mg}$ for slow-acetylators, and magnesium valproate at $40 \mathrm{mg} / \mathrm{kg}$. Both drugs were started at day -7 and continued until chemotherapy ended. Chemotherapy consisted of the same pre-study protocol regimen on which patients progressed. Response and toxicity were evaluated.

\section{Main findings}

From a total of 27 patients that signed informed consent, 17 patients were evaluable for toxicity and 15 patients for response. The primary sites in the 15 evaluable patients were cervix (3), breast (3), lung (1), testis (1) and ovarian (7) carcinomas. A clinical benefit (complete response, partial response or disease stabilization) was observed in $12(80 \%)$ patients, 4 partial responses and 8 stable disease. The treatment was well tolerated even though the studied population was heavily pretreated. The most significant toxicity was hematological. Grade 3 and 4 toxicities were anemia, neutropenia, leukopenia and thrombocytopenia in 23.5\%, 41.1\%, 47\% and $35.2 \%$ respectively. The main non-hematological toxicity was drowsiness, mostly grade 2 . The median survival was 6 months. 


\section{Conclusion}

Hydralazine and magnesium valproate are able to overcome chemotherapy resistance in a heavily treated patient population. The obtaining of partial responses and disease stabilization regardless of the tumor type and chemotherapy schedule strongly supports the concept that epigenetic agents can erase the epigenetic mark associated with the chemoresistant phenotype of cancer cells. These results are in line with our observations in breast and cervical cancer patients that hydralazine and valproate can up-regulate a huge number of tumor suppressor genes. Thus, epigenetic therapy with hydralazine and valproate can be added to the armamentarium for cancer therapy.

Publish with Biomed Central and every scientist can read your work free of charge

"BioMed Central will be the most significant development for disseminating the results of biomedical research in our lifetime. " Sir Paul Nurse, Cancer Research UK

Your research papers will be:

- available free of charge to the entire biomedical community

- peer reviewed and published immediately upon acceptance

- cited in PubMed and archived on PubMed Central

- yours - you keep the copyright 